\title{
COMMENTS
}

\section{Defining the Project Purpose under NEPA: Promoting Consideration of Viable EIS Alternatives}

\author{
Jason J. Czarnezki†
}

\section{INTRODUCTION}

The National Environmental Policy Act of $1969^{1}$ ("NEPA") mandated major changes in the decisionmaking processes of federal agencies. NEPA encourages comprehensive, scientific, and systematic analysis of environmental problems by using procedural requirements to generate information for agency and public benefit. Under NEPA, all federal agencies must submit an environmental impact statement ("EIS") for any federal action that significantly affects the environment. Importantly, an EIS requires discussion of alternatives to the proposed action. ${ }^{3}$ Significantly, however, only those alternatives that can achieve the project's purpose need be discussed. ${ }^{4}$

A federal agency may narrow the stated purpose of a proposed action in an EIS in order to narrow the scope of alternatives it must consider under NEPA. The extent, however, to which an agency may lawfully manipulate its stated project purpose remains unclear. For example, if the U.S. Postal Service seeks to build a new mail facility at

\footnotetext{
$\dagger$ A.B. 2000; J.D. Candidate 2003, The University of Chicago.

1 National Environmental Policy Act of 1969, Pub L No 91-190, 83 Stat 852 (1970), codified at 42 USC $\$ 4321$ et seq (2000).

2 See 42 USC $\$ 4332(2)(C)$.

3 See 42 USC $\S \S 4332$ (2)(C)(iii), (2)(E). See also 40 CFR $\S 1502.14$ (a) (2001) (directing agencies to "[r]igorously explore and objectively evaluate all reasonable alternatives" to the proposed action).

4 See City of Angoon v Hodel, 803 F2d 1016, 1021 (9th Cir 1986) ("When the purpose [of a project] is to accomplish one thing, it makes no sense to consider the alternative ways by which another thing might be achieved."); Natural Resources Defense Council, Inc v Morton, 458 F2d 827,833 (DC Cir 1972) (stating that NEPA only requires an analysis of "alternative ways of accomplishing the objectives of the proposed action").

5 See City of Caramel-by-the-Sea v United States Department of Transportation, 123 F3d 1142,1155 (9th Cir 1997) ("The stated goal of a project necessarily dictates the range of 'reasonable' alternatives and an agency cannot define its objectives in unreasonably narrow terms."). See also Simmons v United States Army Corps of Engineers, 120 F3d 664, 670 (7th Cir 1997) (noting that an agency "executed an end-run around NEPA's core requirement" by accepting a narrow objective, since the agency "never looked at an entire category of reasonable alternatives" that fell outside the narrow objectives of the EIS).
} 
a specific location, should it nevertheless broadly interpret the goal of this particular action as finding a suitable location for a facility ? $^{6} \mathrm{Or}$, suppose the Federal Aviation Administration proposes to expand the Toledo airport for a cargo airline company. Is the agency's purpose specifically to expand Toledo's airport, or, more broadly, to find a suitable location for the company's expansion?

This Comment examines how courts should construe EIS project goals under NEPA. Part I provides the basic foundation for EIS alternative analysis by outlining NEPA's goals, framework, and legal development. Part II identifies and discusses two conflicting positions in current caselaw supporting narrow versus general goal formulations in project purpose evaluation. To resolve this conflict, Part III suggests that courts should reject the narrow formulation in evaluating a project's purpose and objectively inquire into the effect and purpose of the agency's action.

\section{EVALUATING EIS ALTERNATIVES UNDER NEPA}

In order to meet the stated goals of NEPA and adequately complete the EIS process, agencies must consider all alternatives, even those not within the agency's competence. However, the agency need not consider those possibilities that are technologically infeasible.

\section{A. NEPA and the EIS Process}

NEPA may be the United States's most influential and vital environmental law. NEPA promotes environmental responsibility by requiring agencies to generate, consider, and release information on the expected environmental consequences of proposed actions. ${ }^{8}$ The EIS framework emphasizes NEPA's goal of ensuring broad discussion of environmental consequences and urges agencies "to use all practicable means" to improve the environment.' Thus, an EIS must include discussion of a wide range of alternatives to an agency's proposed course of action. ${ }^{10}$

6 See, for example, Village of Palatine v United States Postal Service, 742 F Supp 1377, 1392 (ND Ill 1990) (holding that the narrow objective of building a new mail facility should nevertheless be considered to have a broad goal of finding a suitable location).

7 The D.C. Circuit found that the Federal Aviation Administration could define the project purpose as the expansion of the Toledo airport, rather than the expansion of any of several airports in the wider region. See Citizens Against Burlington, Inc v Busey, 938 F2d 190, 198 (DC Cir 1991).

$8 \quad$ See 42 USC $\$ 4332$.

942 USC $\$ 4331(\mathrm{~b})$.

10 See 42 USC $\$ 4331$ (b)(3)-(6) (including alternatives that may limit environmental degradation, preserve historical and cultural landmarks, balance population and resource use, recycle depletable resources, and enhance renewable resources). 
The EIS process has many beneficial effects. " NEPA forces federal agencies to produce information for use in their own decisionmaking process about the environmental consequences of their actions. By requiring the agency to produce information concerning a project's potential impact on the environment, NEPA expands the existing informational base upon which governmental decisions are made $^{12}$ and forces agencies to "think more carefully about the environment before acting.",

Section 102(2)(C) of NEPA requires that all federal agencies prepare an EIS prior to undertaking "major Federal actions significantly affecting the quality of the human environment." $\mathrm{A}$ "major Federal action" is an action "with effects that may be major and which are potentially subject to Federal control and responsibility." ${ }^{\text {, Such }}$ actions include projects financed, conducted, assisted, regulated, or approved by a federal agency, even if proposed and carried out by a third party.

NEPA requires the agency to produce and make publicly available a "detailed statement" (in other words, the EIS) of environmental impacts of the proposed action, alternatives to the proposed action, any irretrievable commitments of resources involved, and any mitigation measures that might be available. ${ }^{17}$ Section 102(2)(E) requires that all federal agencies study alternatives to actions that involve unresolved conflicts concerning alternative uses of available resources. ${ }^{18}$

The requirement that the agency analyze project alternatives in an EIS may be the heart of NEPA, since these alternatives may ultimately allow the agency to meet project goals in a way that minimizes harm to the environment. In performing this analysis in an EIS, the agency must consider three questions..$^{19}$ First, what is the purpose of

11 For a general discussion of NEPA's mandate, see K.S. Weiner, Basic Purposes and Policies of the NEPA Regulations, in Ray Clark and Larry Canter, eds, Environmental Policy and NEPA: Past, Present, and Future 61, 62-63 (St. Lucie 1997).

12 See Vermont Yankee Nuclear Power Corp v National Resources Defense Council, Inc, 435 US 519, 558 (1978) (stating that NEPA's mandate "is to insure a fully informed and wellconsidered decision"); Weiner, Basic Purposes and Policies of the NEPA Regulations at 64 (cited in note 11) (stating that NEPA's process is meant to inform planning and decisionmaking, not serve as a substitute for it).

13 Serge Taylor, Making Bureaucracies Think: The Environmental Impact Statement Strategy of Administrative Reform 5 (Stanford 1984).

1442 USC $\$ 102(2)(C)$.

1540 CFR $\S 1508.18$. "Significantly" and "Human environment" are defined in 40 CFR $\S 1508.27$ and 40 \& CFR 1508.14 , respectively.

16 See 40 CFR $\$ 1508.18$.

17 See 42 USC $\$ 4332(2)(C)$.

1842 USC $\$ 102(2)(E)$.

19 See Simmons v United States Army Corps of Engineers, 120 F3d 664, 668-69 (7th Cir 1997) (describing the logical three-step EIS analysis), citing City of Caramel-by-the-Sea $v$ United States Department of Transportation, 95 F3d 892,903 (9th Cir 1996), and City of Grapevine, Texas 
the proposed project (the "major Federal action") $?^{20}$ Second, given that purpose, what are the reasonable alternatives to the project? And third, to what extent should the agency explore each particular reasonable alternative $?^{22}$ Because the answer to the first question - the purpose of the proposed project-strongly influences how courts and agencies respond to the remaining two questions, this question should be the focus of the analysis. The remainder of Part I, however, lays the groundwork for this focus by establishing how courts have analyzed the second and third steps of the EIS process.

\section{B. Morton: Examining Alternatives}

The D.C. Circuit provided a framework to answer the second question - the scope of reasonable alternatives - in Natural Resources Defense Council, Inc v Morton. ${ }^{23}$ In that case, the Natural Resources Defense Council ("NRDC") and other environmental groups challenged the adequacy of the United States Department of Interior's EIS, which focused on a proposal for oil and gas general lease sales for tracts of submerged lands off the coast of Louisiana. ${ }^{24}$ The government contended that the only alternatives that needed to be considered under NEPA were those that could be adopted and put into effect by the official or agency issuing the EIS. ${ }^{25}$

The court disagreed, however, concluding that the alternatives required by NEPA are not limited to those that the agency may adopt. Agencies must also consider reasonable alternatives not within the agency's competence or legal authority. ${ }^{26}$ Thus, the Interior Department should have discussed increasing oil imports as an alternative, even though it could not have implemented this solution unilaterally. The court emphasized that the case involved a broad program of action within the purview of Congress and the President, and such involvement facilitates their ability to create alternatives as well. ${ }^{27}$ Thus, discussing legislative action as an alternative may be required, so long as the issues are not highly speculative (for example, repealing antitrust laws). ${ }^{28}$

\footnotetext{
$v$ United States Department of Transportation, 17 F3d 1502, 1506 (DC Cir 1994).

20 See Simmons, 120 F3d at 668-69.

21 See id.

22 See id.

23 See 458 F2d 827, 827 (DC Cir 1972).

24 Id.

25 Id at 834.

26 See id at 837 (noting that "the mere fact that an alternative requires legislative implementation does not automatically establish it as beyond the domain of what is required for discussion" in an EIS).

27 See id at 835 .

$28 \quad$ See id at 837.
} 
The court also stated that it is inappropriate to disregard alternatives that do not offer a complete solution." "Where the environmental aspects of alternatives are readily identifiable by the agency, it is reasonable to state them." ${ }^{, 30}$ The Morton court justified this broad interpretation of NEPA by arguing that "NEPA was intended to provide a basis for consideration and choice by decision-makers in the legislative as well as the executive branch, ${ }^{, 31}$ and that NEPA establishes sensible and reasonable principles to use in order to weigh which alternatives must be considered.

\section{Vermont Yankee:To What Extent Must Alternatives Be Considered?}

After determining which alternatives an agency must consider, courts must also examine the extent to which an agency must consider those alternatives. In answering this question, the Supreme Court has interpreted NEPA's requirements less broadly than the D.C. Circuit did in deciding which alternatives to consider in Morton. Vermont Yankee Nuclear Power Corp v Natural Resource Defense Council, Inc ${ }^{33}$ involved an Atomic Energy Commission licensing proceeding for a nuclear power plant being built by Consumers Power. ${ }^{34}$ The Court considered whether NEPA required the Commission to re-open proceedings to further examine energy conservation measures as an alternative to plant construction. ${ }^{35}$ The D.C. Circuit ruled that the Commission's "threshold test" for the presentation of energy conservation contentions, which requires a showing to be "sufficient to require reasonable minds to inquire further," was inconsistent with NEPA's basic mandate and suggested that the Commission must investigate an alternative if an intervenor's comments "bring sufficient attention to [it]." ${ }^{36}$ The Court, however, upheld the Commission's actions and its more narrow "threshold test.",

The Court chose not to require that energy conservation be discussed as an alternative to plant construction under NEPA because it believed that the agency must only consider feasible alternatives. ${ }^{38}$ At

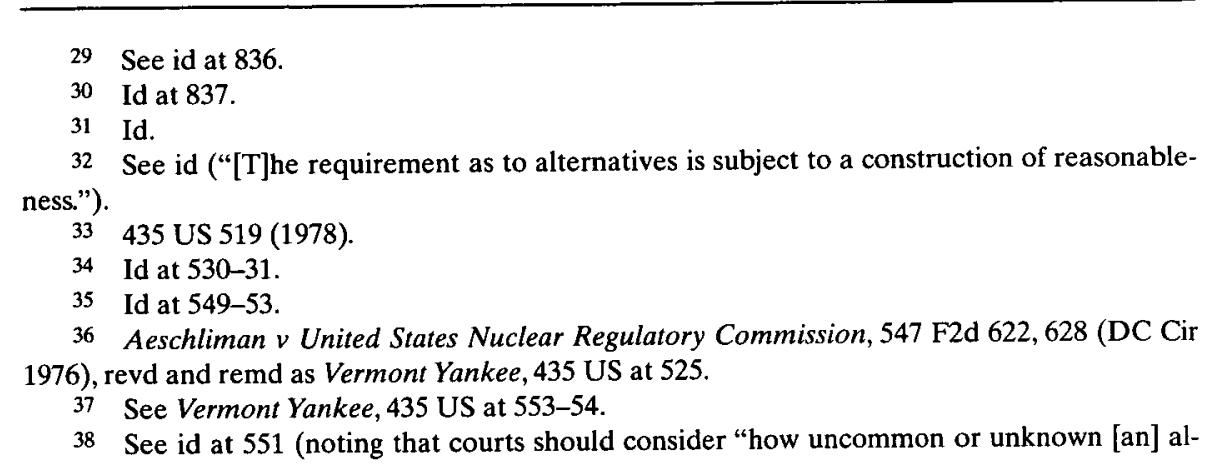


the time, there was little information available about the benefits of national energy conservation. Vermont Yankee's holding thus recognizes that alternatives need not be considered if there is a lack of information concerning their feasibility.

\section{Conceptions of Morton and Vermont Yankee: Attempting to Increase Public Scrutiny}

Both Morton and Vermont Yankee endorse public scrutiny of feasible alternatives, although the Morton court appears to advocate a broader conception of what NEPA requires. ${ }^{39}$ By requiring discussion of alternatives that an agency itself cannot implement, ${ }^{40}$ the Morton court succeeds in ensuring public scrutiny of a full range of EIS alternatives. The decision seeks to increase public participation in all branches of government in order to control agency discretion, and objects to a mission-oriented focus of agencies in which environmental considerations are not emphasized. Thus, the court seeks to overcome a fragmentation of the executive branch into different legal authorities.

Although Vermont Yankee's outcome, unlike Morton, limits the discussion of some alternatives, it remains consistent with NEPA's goal of increasing public scrutiny. A narrow reading indicates that agencies need only consider technologically remote alternatives (like energy conservation at that time ${ }^{41}$ ) if properly and sufficiently presented by a third party. ${ }^{42}$ Although one might object that Vermont Yankee encourages governmental ignorance, NEPA is not so expansive as to require that agencies be on the technological forefront. Read together, Morton and Vermont Yankee suggest that agencies need not, or at least have a lesser duty to, consider alternatives when they are politically remote (such as repealing antitrust laws ${ }^{43}$ ) or technologically and scientifically remote. These cases may further suggest that agencies must consider more remote alternatives if adequately and substantively suggested by intervenors with concrete information and data. ${ }^{44}$ In this

\footnotetext{
ternative may have been at the time the project was approved" when reviewing adequacy of alternatives).

39 See Morton, 458 F2d at 834; Part I.B.

40 See Morton, 458 F2d at 834.

41 See Vermont Yankee, 435 US at 552, 554 (noting that the general importance of energy conservation did not become clear until at least a year after the completion of the environmental statement at issue).

42 See id at 554 (noting that third parties failed to provide the agency with sufficient data regarding feasible alternatives).

43 See Morton, $458 \mathrm{~F} 2 \mathrm{~d}$ at 837 (stressing that the definition of alternatives demands reasonableness).

44 See Vermont Yankee, 435 US at 554 (suggesting that the intervenor's refusal to provide specificity to "energy conservation" alternative supported a finding that the agency's decision
} 
way, Vermont Yankee, like Morton, supports the evaluation of new alternatives and supports NEPA's objective of increasing public scrutiny.

\section{GENERAL GOAL VERSUS NARROW FORMULATION}

A proper method of judicial inquiry into an EIS project purpose can ensure that an appropriate range of alternatives will be considered. This Part analyzes two methods of defining the purpose of the proposed project (an inquiry that precedes, but ultimately influences, the sufficiency of alternatives analysis discussed in Morton and Vermont Yankee). The first method takes a broader approach using a general goal formulation, and the second method views the underlying purpose more narrowly. Each has a basis in the case law, and embodies a particular view of NEPA.

\section{A. A Broader Approach: General Goal Formulation}

1. Defining the general goal formulation, its foundation, and its role.

Under a broad formulation of an EIS purpose, NEPA requires the court to evaluate the "alternative means to accomplish the general goal of an action ... [not] the alternative means by which a particular applicant can reach his goals." ${ }^{45}$ As the introductory example notes, if the U.S. Postal Service seeks to build a new mail facility at a specific location, its goal can be broadly interpreted as finding a suitable location.

Under this view, for proposals initiated by third parties agencies need to concern themselves with a project's general goal rather than relying on the information provided by the applicant. Federal agencies themselves must determine what alternatives are reasonably available. ${ }^{47}$ Allowing an agency to abandon this requirement establishes "a precedent that will permit an applicant and a third-party beneficiary of federal action to define the limits of the EIS inquiry and thus to

not to address it was not arbitrary).

45 Van Abbema v Fornell, 807 F2d 633, 638 (7th Cir 1986).

46 See Village of Palatine v United States Postal Service, 742 F Supp 1377, 1392 (ND Ill 1990) (determining that when the Postal Service considered and ruled out leasing an existing structure and therefore decided to construct a new building, its general goal remained the same-finding a suitable location-and the Postal Service's responsibilities under NEPA required it to consider alternative sites of construction in finding a suitable location).

47 See Citizens Against Burlington, Inc v Busey, 938 F2d 190, 209 (DC Cir 1991) (Buckley dissenting), quoting Trinity Episcopal School Corp v Romney, 523 F2d 88, 94 (2d Cir 1975). See also Van Abbema, 807 F2d at 642 (condemning the Army Corps of Engineers' "blind reliance on material prepared by the applicant"). 
frustrate one of the principal safeguards of the NEPA process, the mandatory consideration of reasonable alternatives." ${ }^{48}$

The Seventh Circuit has explicitly endorsed the general goal standard in its decisions. In Van Abbema v Fornell, ${ }^{49}$ the Army Corps of Engineers ("Corps") received a request for permission to build a facility to transport coal from trucks to barges. ${ }^{50}$ The court decided that the Corps had to survey "feasible alternatives [to] the applicant's proposal," including all reasonable alternative ways of accomplishing "the general goal [of] deliver[ing] coal from mine to utility.", In Hoosier Environmental Council, Inc v United States Army Corps of Engineers, ${ }^{52}$ while evaluating a riverboat casino proposal, the court followed Van Abbema and decided the proposal's general purpose was "to develop a site for placement of a highly-regulated activity."

In Simmons $v$ United States Army Corps of Engineers, ${ }^{\text {s. }}$ the Seventh Circuit confirmed that deference to a stated project purpose "is a losing position" and rejected the purpose presented by the Corpscreating a single water supply source to two communities-as unreasonable. ${ }^{\text {s5 }}$ The Simmons court stated that the project's general purpose was to increase the communities' water supply, which would permit consideration of alternatives beyond that of relying on a single reservoir. ${ }^{56}$ The court condemned blind reliance on material prepared by an applicant: "An agency cannot restrict its analysis to those "alternative means by which a particular applicant can reach his goals."," The Simmons court noted that the Corps must exercise independent judgment in defining the purpose and need for the project from both the applicant's and the public's perspective. ${ }^{59}$

2. Further application of the general goal formulation.

The district courts of the First Circuit have accepted the general goal formulation of looking to the underlying goals of the project under NEPA. ${ }^{60}$ In Sierra Club v Marsh, ${ }^{61}$ the court stated that parties

48 Citizens Against Burlington, 938 F2d at 209 (Buckley dissenting).

49807 F2d 633 (7th Cir 1986).

50 Id at 635 .

51 Id at 638.

52 105 F Supp 2d 953 (SD Ind 2000).

53 Id at $1000 \& \mathrm{n} 23$.

54120 F3d 664 (7th Cir 1997).

55 See id at 669.

56 Id.

57 See id.

58 Id, quoting Van Abbema, 807 F2d at 638. But see Citizens Against Burlington, 938 F2d at 199 ("Congress did not expect agencies to determine for the applicant what the goals of the applicant's proposal should be.").

59 Simmons, 120 F3d at 669 n 1, citing 33 CFR Pt 325, App B, § (9)(b)(4)-(5) (2001).

60 See, for example, Sierra Club v Marsh, 714 F Supp 539, 573-74 (D Me 1989), citing Van 
should address "whether, under NEPA, the reasonableness of any alternative is to be measured against general project goals similar to those enunciated in the [EIS], or against the scope of the proposed project in its initial phase., ${ }^{, 62}$ In addressing this question, the Sierra $C l u b$ court adopted the general goal formulation. ${ }^{63}$

\section{B. Narrow Formulation}

1. Defining the narrow formulation, its foundation, and its role.

Under the narrow formulation of the project purpose, agencies may limit their consideration of alternatives by narrowing the definition of a project's purpose. ${ }^{64}$ The narrow formulation gives extreme deference to agencies in defining the project purpose and advocates agency responsibility for this definition."

In Citizens Against Burlington, Inc v Busey, ${ }^{\circ}$ the D.C. Circuit noted the difficulty in drawing a distinction between the stated and general goal of the project and determining who should make such a distinction, ${ }^{67}$ considering that a project's purpose can be characterized at various levels of specificity. The D.C. Circuit chose not to develop criteria in order to make a determination of the actual project purpose. Indeed, the Citizens Against Burlington court, "trouble[d]" by the Seventh Circuit's assertion that an agency must evaluate "alternative means to accomplish the general goal of an action," noted that "[s]omeone has to define the purpose of the agency action."

\footnotetext{
Abbema, 807 F2d at 638 .

61714 F Supp 539 (D Me 1989).

62 Id at 573, citing Van Abbema, 807 F2d at 638.

63 See Sierra Club, 714 F Supp at 577. See also Coalition For Canyon Preservation v Bowers, 632 F2d 774, 783-84 (9th Cir 1980) (holding that the improvement of a two-lane road was a reasonable alternative to the proposed four-lane highway); Trout Unlimited $v$ Berry, 509 F2d 1276,1286 (9th Cir 1974) (identifying the primary goals of the Teton Dam and Reservoir Project as flood control and establishment of irrigation water source); Van de Kamp v Marsh, 687 F Supp 495, 499 (ND Cal 1988) (relocating or scaling back a project designed to create additional air cargo and create additional capacity at a specific airport should be considered a reasonable alternative); Residents in Protest-I-35E v Dole, 583 F Supp 653, 660 (D Minn 1984) (noting that "it is not permissible to define the goals [of a project] in such a manner so as to preordain the outcome," and that "a reasonable alternative is one which serves the underlying goals of a project") (emphasis added).

64 See, for example, Citizens Against Burlington, Inc v Busey, 938 F2d 190, 198-99 (DC Cir 1991) (holding that alternatives beyond taking no action at all did not need to be considered in a proposal to construct a new cargo hub for Burlington Air Express, Inc. at the Toledo Express Airport, despite the objection that the general purpose of the project was to provide a permanent cargo hub for Burlington Air, and that an expansion of their current Fort Wayne facility was a viable alternative).

65 See id at 195-96.

66938 F2d 190 (DC Cir 1991).

67 See id at 199.

68 Id.
} 
body responsible is not the reviewing court $:^{69}$ rather, according to the D.C. Circuit, NEPA and case law suggest that courts should defer to the administrative agency or the applicant's individual proposal. ${ }^{70}$

The D.C. Circuit closely scrutinized the statutory language of NEPA in creating its narrow formulation of the project purpose, and criticized the Van Abbema court as misconstruing the language of NEPA:

An agency cannot redefine the goals of the proposal that arouses the call for action; it must evaluate alternative ways of achieving its goals, shaped by the application at issue and by the function that the agency plays in the decisional process. Congress did expect agencies to consider an applicant's wants when the agency formulates the goals of its own proposed action. Congress did not expect agencies to determine for the applicant what the goals of the applicant's proposal should be."

The D.C. Circuit concluded that NEPA commands agencies to discuss alternatives to the proposed " "major Federal actions' ... and not to alternatives to the applicant's proposal."

2. Further application of the narrow formulation.

The narrow formulation has been applied and implicitly accepted by district courts within the Ninth Circuit ${ }^{73}$ In Kettle Range Conservation Group v United States Forest Service, the court stated that it was "not aware of any case in which the Ninth Circuit found a statement of purpose to be unreasonably narrow." ${ }^{, 75}$ For instance, the Ninth Circuit has found proposals that called for a specific land-swapping plan or a specific amount of timber harvest to be sufficiently broad formulations of the underlying purpose. ${ }^{76}$ Thus, the Ninth Circuit routinely rejects the argument that a stated purpose is too narrow.

69 Id.

70 See id.

71 Id.

72 Id, quoting 42 USC $\$ 4332(2)(\mathrm{C})$.

73 This has occurred despite the Ninth Circuit's ambiguous conclusion in City of Caramelby-the-Sea v United States Department of Transportation that "an agency cannot define its objectives in unreasonably narrow terms." 123 F3d 1142, 1155 (9th Cir 1997).

74148 F Supp 2d 1107 (ED Wash 2001).

75 Id at 1117-18 (upholding a statement of purpose that called for a specific solution, "timber harvest," to a general problem, "the Douglas-fir beetle outbreak").

76 See, for example, Muckleshoot Indian Tribe v United States Forest Service, 177 F3d 800, 812-13 (9th Cir 1999) (validating the Forest Service's statement of purpose to "consolidate ownership and enhance future resource conservation and management by exchanging parcels of $\mathrm{Na}$ tional Forest System and Weyerhaeuser land," even though this statement of purpose essentially ruled out any alternatives that did not closely resemble the parties' pre-existing land-swapping plan); Friends of Southeast's Future v Morrison, 153 F3d 1059, 1066-67 (9th Cir 1998) (upholding 


\section{An Interpretive Continuum}

There is not a sharp dichotomy between any narrow and general formulation of the project's purpose, but rather a continuum by which the purpose can be manipulated and described at levels of specificity in either direction. ${ }^{78}$ The Tenth Circuit alluded to this view in Colorado Environmental Coalition v Dombeck. ${ }^{79}$ Attempting to reconcile Citizens and Van Abbema, the Tenth Circuit did not "perceive these authorities as mutually exclusive or conflicting":

They simply instruct agencies to take responsibility for defining the objectives of an action and then provide legitimate consideration to alternatives that fall between the obvious extremes. Beyond this, there are no hard and fast rules to guide the alternatives analysis."

However, the Tenth Circuit fails to recognize the stated purposes' strong impact on such an analysis, and, like other circuits, fails to answer how one can determine whether an agency has, in fact, defined project objectives responsibly.

\section{CEQ Regulations and Hard Look Review}

Once courts have determined the proper scope of the underlying project goal, they must still determine which goals are consistent with that formulation. To do so, courts can look to the CEQ guidelines, which develop guidelines for agency compliance with $\mathrm{NEPA}^{82}$ and contain explicit guidance "concerning limitations on an applicant's power to prescribe the project criteria for use in considering the feasibility of alternatives."

a stated purpose of "providing 89 [million board feet] of timber to meet market demand," despite the fact that this statement of purpose explicitly foreclosed any and all consideration of an alternative which would provide a lesser amount of timber to the market).

77 See note 76.

78 Accepting this view, the issue then becomes focused on whether an agency's narrowly stated purpose should be accepted under NEPA and allowed to prohibit any broader inquiry.

79185 F3d 1162, 1174-76 (10th Cir 1999) (attempting to reconcile the narrow and general goal formulations, and determining that the Forest Service's consideration of alternatives for ski area construction, including mitigation and "no action," satisfied the rule of reason).

80 Id at 1175 .

81 Id.

82 See, for example, Council on Environmental Quality, Forty Most Asked Questions Concerning CEQ's National Environmental Policy Act Regulations, 46 Fed Reg 18026, 18027 (Mar 23, 1981).

83 Sierra Club, 714 F Supp at 574. The court further noted:

[A]lthough "[ $t]$ here is no ... need to disregard the applicant's purposes and needs and the common sense realities of a given situation in the development of alternatives," ... "[r]easonable alternatives include those that are practical or feasible from the technical and economic standpoint and using common sense, rather than simply desirable from the 
constrain the ability of third parties to limit the project purpose (and the alternatives considered by the agency). These regulations are a "single set of uniform, mandatory regulations" that are "entitled to substantial deference by the courts." ${ }^{84}$ Thus, a project's purpose is required to be properly stated by the regulations promulgated pursuant to NEPA.

Judicial review of the sufficiency of the stated project purpose is done under the hard look doctrine. The hard look doctrine ensures that every EIS relied on the statutorily relevant factors, offered reasonable explanations for its decision, helped to explore the relevant alternatives, and offered participation to the involved parties. ${ }^{85}$ The CEQ regulations, however, fail to provide the relevant factors in considering whether an agency has adequately formulated the project purpose. Similarly, courts such as the Seventh Circuit in Van Abbema and Simmons do not provide any discernable or objective criteria to determine a project's general goal.

\section{Resolving How to CONSTRUe EIS PROJECT PURPOSES}

This final Part creates explicit and workable rules for the continuum of project purposes when engaged in hard look review. Courts

standpoint of the applicant."

Id at 574, citing Council on Environmental Quality, Guidance Regarding NEPA Regulations, 48 Fed Reg 34263, 34267 (July 28, 1983) and 46 Fed Reg at 18027 (cited in note 82), respectively.

84 Andrus v Sierra Club, 442 US 347, 357-58 (1979).

85 See Scenic Hudson Preservation Conference v Federal Power Commission, 354 F2d 608, 612 (2d Cir 1965) (chastising the agency after it "ignored certain relevant factors and failed to make a thorough study of possible alternatives"). See also Citizens to Preserve Overton Park, Inc $v$ Volpe, 401 US 402,416 (1971) (noting that courts "must consider whether the [agency] decision was based on a consideration of the relevant factors and whether there has been a clear error of judgment"); Citizens Against Burlington, 938 F2d at 196 (stating that "agencies must look hard at the factors relevant to the definition of purpose" when beginning an EIS).

86 It could be argued that any inquiry into the project purpose will be less than helpful due to the malleable nature of any answer, and that any such "purposes test" should be rejected in favor of a more pragmatic rule of reason test like that in Morton. However, if the purposes test cannot be avoided, any such pragmatic inquiry will come too late and after the fact. NEPA only requires that an EIS include alternatives that will fulfill the project's purpose. See 42 USC $\S 4332(2)$ (C)(iii); Morton, 458 F2d at 833; City of Angoon v Hodel, 803 F2d 1016, 1021 (9th Cir 1986). Thus, it may be statutorily and legally implausible to avoid evaluating the goal of the major federal action at issue. In some ways the pragmatic test may prove insufficient if the project's purpose is in fact defined narrowly, prematurely limiting the scope of alternatives. This is not to say that the more pragmatic Morton reasonableness inquiry is incompatible with the objective inquiry into the project's purpose. The two are complementary. Once the underlying goal of the project is defined, courts should then use a reasonableness standard (as advocated in Morton) to require that a sufficient range of alternatives be considered.

87 This analysis is essential as federal agencies do not receive deference when interpreting NEPA or regulations promulgated under NEPA because no single agency is charged with administering the statute. See Chevron USA, Inc v Natural Resources Defense Council, Inc, 467 US 837, 843-44 (1984) (requiring courts to give deference to an agency's statutory interpretations when Congress expressly or implicitly delegates exclusive interpretative authority over that statute to 
should (a) explicitly reject the narrow formulation, (b) have a general rule rejecting stated project purposes that result in the disclosure of no alternatives, and (c) objectively inquire into any asserted purposes. Such an approach is supported by, and consistent with, the purposes of NEPA.

A. A Dual Analysis: Rejecting the Narrow Formulation in Favor of a Broader Inquiry

1. Interpretive analysis.

Tools of statutory interpretation, including reviewing statutory language, legislative history, and overall statutory purpose, support rejection of the narrow formulation. Textually, the narrow formulation contradicts the explicit language of NEPA, which requires agencies to perform their NEPA duties "to the fullest extent possible."

In contrast to NEPA's statutory encouragement of diverse public and private involvement, ${ }^{89}$ the narrow formulation limits involvement to that of the proposing agency or third party. Such a limitation defeats NEPA's mandate to "[r]igorously explore and objectively evaluate all reasonable alternatives." ${ }^{, 00}$ The narrow formulation also limits the ability of an EIS to reflect alternatives that may limit environmental degradation, ${ }^{91}$ preserve historical and cultural landmarks, ${ }^{92}$ balance population and resource use, ${ }^{93}$ and recycle and properly use renewable and depletable resources. ${ }^{94}$ Because NEPA's goals are so broad and numerous, it is unlikely that a narrowly stated purpose could satisfy many of them. As alternatives increase, the likelihood of satisfying these several goals increases, and agencies, through a public and democratic process, can choose among them.

The legislative history implicitly supports a broader interpretation of the project purpose and illustrates Congress's intention that all alternatives to the proposed action must be considered "to the fullest extent possible" in a detailed statement."

an agency). Chevron also does not apply to Council of Environmental Quality interpretations of NEPA because these regulations were not adopted pursuant to any delegated authority from Congress. See id. For a general discussion, see Thomas W. Merrill and Kristin E. Hickman, Chevron's Domain, 89 Georgetown L J 833, 893-95 (2001).

8842 USC $\$ 4332$.

89 See 42 USC $\$ 4331$ (outlining several areas of federal responsibility for environmental protection, while recognizing that "each person has a responsibility to contribute to the preservation and enhancement of the environment").

90 See 40 CFR $\S 1502.14(a)$.

9142 USC $\$ 4331(\mathrm{~b})(3)$.

9242 USC $\$ 4331(\mathrm{~b})(4)$.

9342 USC $\$ 4331(\mathrm{~b})(5)$.

$94 \quad 42$ USC $\$ 4331(b)(6)$.

95 National Environmental Policy Act of 1969, Conf Rep No 91-765, 91st Cong, 1st Sess 3 
Supporters of the narrow formulation argue that Congress intended agencies to have wide discretion in defining a project's purpose under NEPA, especially if a proposal is submitted by a third party. These supporters assert that NEPA only requires agencies to discuss alternatives to proposed "'major Federal actions significantly affecting the ... environment,' and not to alternatives to the applicant's proposal." ${ }^{, 6}$ Under this view, an agency cannot redefine the goals of the proposal that creates the call for action; rather, an agency must evaluate alternative means of achieving a project's goals by focusing on the stated purpose of the application at issue and the function that the agency plays in the decisional process. ${ }^{97}$ The narrow view postulates that Congress sought to give broad discretion to agencies in considering the goals of its own proposed action, but "did not expect agencies to determine for the [individual] applicant what the goals of the applicant's proposal should be." ${ }^{98}$

Congress did not intend this result. NEPA's legislative history indicates that Congress was concerned with the potentially self-serving missions of individual agencies, and therefore sought to limit agency discretion:

It is a simple fact of life that policies of agencies of the Federal Government may and do conflict: it is equally true that there are occasions where, without the benefit of conflicting policies, these Government agencies may and do adopt courses that appear to conflict with the general public interest."

Narrow construction of a project's purpose further aggravates these concerns and permits greater agency discretion in choosing among an indefinite number of narrowly stated purposes. This decreases political accountability and allows agencies to promote policies in their own self-interest, while evading NEPA's EIS goals of increasing public scrutiny and adequately considering alternatives.

Furthermore, the broad conception is embodied in the CEQ regulations, which should be afforded substantial deference by courts. As mentioned above, the CEQ regulations serve to constrain the abil-

\footnotetext{
(1969), reprinted in 1969 USCCAN 2769.

96 Citizens Against Burlington, 938 F2d at 199, citing 42 USC $\S 4332(2)(C)$.

97 However, there is no statute or regulation that mandates agencies to treat federal and non-federal applicants differently. The Citizens Against Burlington court relied purely on NEPA's statutory plain language to support this argument. See Citizens Against Burlington, $938 \mathrm{~F} 2 \mathrm{~d}$ at 199; Michael E. Lackey, Jr., Misdirecting NEPA: Leaving the Definition of Reasonable Alternatives in the EIS to the Applicants, 60 Geo Wash L Rev 1232, 1269-71 (1992) (arguing that the statutory plain language argument in Citizens Against Burlington "is unworkable," because the "applicant's proposal is not a separate entity distinct from the major federal action").

98 Citizens Against Burlington, 938 F2d at 199.

99 National Environmental Policy Act of 1969, HR Rep No 91-378, 91st Cong, 1st Sess 3-4 (1969), reprinted in 1969 USCCAN 2753-54.
} 
ity of parties to limit the project purpose and the alternatives considered by agencies. ${ }^{100}$

In addition to statutory language and legislative history conflicts, the narrow formulation violates the broad conception and purposes of NEPA advocated in cases like Morton. By requiring a broader inquiry and allowing the discussion of alternatives that the agency itself cannot implement, public scrutiny of a full range of EIS alternatives is ensured. Morton supports NEPA's objection to mission-oriented agencies where environmental considerations are not emphasized.

\section{Functional analysis.}

Although advocates of both the narrow and general goal formulations struggle with functional issues of judicial economy, efficiency, and responsibility, only a broader formulation maintains consistency with each, and more fundamentally, seeks to pursue NEPA's stated goals. However, supporters of the narrow formulation argue that the narrow formulation promotes judicial clarity and economy, since it is easier to accept the stated purpose of a project than to objectively determine its general purpose. Efficiency arguments aside, proponents of the narrow view argue that it is not the proper role of the court to be responsible for this decision, and that deference should be given to the administrative agency's determination or the applicant's proposal.

In rejecting the narrow formulation, proponents of a broader inquiry into the project's purpose are also concerned with problems of implementation and informational bureaucracy. However, a broader inquiry (including any objective, standard-based inquiry) that is consistent with Vermont Yankee will be reasonably bounded in scope and will not result in any bureaucratic mess in which each agency must explore each particular reasonable alternative. Because the inquiry is so bounded, the broader inquiry will not result in the efficiency losses feared by its critics.

When an agency uses a broader formulation of the project purpose, the agency will be required, under Vermont Yankee, to exclude speculative or non-feasible alternatives. ${ }^{101}$ This consequently cuts down on the time spent by the agency in preparing the EIS. Under a narrow reading of Vermont Yankee, agencies are not required to consider alternatives when they are politically or technologically remote. ${ }^{102}$ Agencies must only consider remote alternatives if they are adequately and

\footnotetext{
100 See Part II.D.

101 See 435 US at 552, 554.

102 See id.
} 
substantively suggested by interveners with concrete information and data.

The narrow formulation, supporters argue, can curtail further EIS inefficiency. NEPA has been condemned on the grounds that it imposes costly and useless paper-processing requirements on federal agencies and private parties. ${ }^{104}$ For all its acclaimed virtues, critics claim that NEPA "in practice turns out to be a less elegant, efficient, and effective engine for producing and transmitting information than its proponents suppose,"105 and has resulted in a flood of litigation."

103 Id at 554 (noting the failure of third parties to present data on the viability of energy conservation technologies).

104 See Sally K. Fairfax, A Disaster in the Environmental Movement, 199 Sci 743, 743 (1978) (arguing that NEPA has wasted environmentalists' resources on processing papers); H. Paul Friesema and Paul J. Culhane, Social Impacts, Politics, and the Environmental Impact Statement Process, 16 Natural Resources J 339, 339 (1976) (noting that critics have characterized the EIS process as proliferating more paperwork than science). For a general discussion of the virtues and vices of NEPA, see Bradley C. Karkkainen, Toward a Smarter NEPA: Monitoring and Managing Government's Environmental Performance, 102 Colum L Rev 903, 906 (2002) (suggesting that NEPA has "settled into a quiescent and underproductive middle age" of inefficiency).

105 Karkkainen, 102 Colum L Rev at 917 (cited in note 104). An EIS can be hundreds of pages long: in 1996, the average final EIS was 572 pages long with over 200 pages of text, despite CEQ regulations attempting to limit EIS page lengths. See Environmental Protection Agency and Office of Federal Activities, EIS Activity (1996) (on file with author). See also 40 CFR $\S 1502.7$ (stating that the final EIS "text" length normally should be less than 150 pages and proposals of unusual scope or complexity should normally be less than 300 pages). In the year 2000 alone, federal agencies filed at least $389 \mathrm{EISs}$, and research indicates that agencies are producing EISs at a rate of close to 500 per year. See Environmental Protection Agency, Number of Environmental Impact Statements filed by Selected Agencies for the Years 2000, 1999, and 1998 (Sept 2001) (on file with author); Council on Environmental Quality, The 1997 Annual Report of the Council on Environmental Quality, Table 3, Appendix - NEPA Statistical Tables (1997), online at http://ceq.eh.doe.gov/nepa/reports/1997/index.html (visited Feb 22, 2003).

106 Some may argue that adopting the narrow formulation would lessen NEPA's impact as a "paper tiger," and help stop agencies from producing verbose reports containing too much extraneous information in an attempt to become litigation-proof. $\mathrm{H}$. Welles, The CEQ NEPA Effectiveness Study: Learning From Our Past and Shaping Our Future, in Clark and Canter, eds, Environmental Policy and NEPA 193, 201 (cited in note 11). However, it appears that increasing the scope of the EIS does little to prevent litigation; in the early 1990s, the Justice Department was actively involved in 350 NEPA cases, William H. Rodgers, Jr., Environmental Law 818 (West 2d ed 1994), citing Statement of William M. Cohen, Chief, General Litigation Section, Environment and Natural Resources Division, United States Department of Justice, Conference on Environmental Law: NEPA, Seattle, WA, January 27-28, 1993, and in 1997 alone, 102 NEPA cases were filed against federal agencies. CEQ, The 1997 Annual Report of the Council on Environmental Quality, Table 1, Appendix - NEPA Statistical Tables (1997) (cited in note 105). Thus, it appears unlikely that any broader formulation would not further increase EIS volume or result in further litigation. Finally, supporters of the narrow formulation assert that it would lower EIS costs and increase EIS processing speed. See P. Offringa, Creating a User-Friendly NEPA, in Clark and Canter, eds, Environmental Policy and NEPA 289, 294 (cited in note 11) (citing the example of the proposed conversion of Camp Shelby, Mississippi, for which the EIS process "went on for six years while virtually nothing happened"); National Academy of Public Administration, Managing NEPA at the Department of Energy (1998), online at http://www.napawash.org/ pc_economy_environment/recent_publications.html (visited Feb 22, 2003) (stating that thirtyone Department of Energy EISs initiated prior to 1994 had an average cost of $\$ 6.3$ million and a median cost of $\$ 1.2$ million, and after attempts to control costs, the average cost of 16 EISs pro- 
These arguments ignore NEPA's stated goals. Increasing judicial scrutiny by objectively examining a stated project purpose will further serve NEPA's mission by increasing public deliberation of environmental issues via litigation. The typical plaintiff's claim is for failure to prepare an EIS or inadequacy of the EIS. Thus, plaintiff litigation, mostly by public interest organizations, citizen groups, and individuals, ${ }^{107}$ promotes the purpose of adequate consideration of environmental effects. In fact, NEPA statutorily encourages each person to help preserve and maintain a healthy environment. ${ }^{108}$ The proliferation of EIS filings and litigation ensures that the procedural requirements of NEPA are fulfilled. Thus, even if a broader formulation does increase litigation at the margins, such suits may serve the very purposes for which NEPA was originally enacted.

\section{B. A Two-Part Test for Evaluating a Project's Purpose}

Having concluded that some broader formulation of a project purpose better serves NEPA's statutory goals than the strict narrow formulation, this section presents a standard that can guide a court's EIS inquiry when subjecting an agency's stated project purpose to a rigid hard look review.

Courts should use the following two-part test to properly analyze an EIS's stated project purpose when performing a hard look review of how alternatives must be considered under the relevant regulations and NEPA: (1) a determination of whether there are any alternatives presented, followed by, (2) an objective inquiry into the stated project purpose. Such an objective inquiry should consider whether the stated purpose limits the geographical area or location, limits the means or tools of production, specifies a method of implementation, contains a totally inflexible timeframe, or prefers a form of technology.

duced after 1994 was reduced to $\$ 5.1$ million, but the median cost increased to $\$ 2.7$ million). A recent study for the Federal Highway Administration found that an EIS required an average of 3.6 years to complete, with some taking as many as 12 years. Federal Highway Administration, Evaluating the Performance of Environmental Streamlining: Development of a NEPA Baseline for Measuring Continuous Performance $\S 4.1 .1$ (2001), online at http://www.fhwa.dot.gov/ environment/strmlng/baseline/index.htm (visited Feb 22, 2003). Similarly, the Department of Energy reported a median completion time of 33 months for EISs initiated between 1989 and 1994. National Academy of Public Administration, Managing NEPA at the Department of Energy. As a result of the broad information-production requirements enforceable through the courts, the "standard for the quantity of information that must be produced in an EIS is set extremely high, and the process is painfully slow and costly." Karkkainen, 102 Colum L Rev at 919 (cited in note 104).

107 See CEQ, The 1997 Annual Report of the Council on Environmental Quality, Table 2, Appendix-NEPA Statistical Tables (1997) (cited in note 105) (reporting 75 of 102 NEPA plaintiffs were public interest organizations, citizen groups, or individuals).

108 See 42 USC $\$ 4331$ (c) ("The Congress recognizes ... that each person has a responsibility to contribute to the preservation and enhancement of the environment."). 
1. Part one:Automatic rejection if no alternatives are presented.

Courts should have a general rule that in the absence of any stated EIS alternative, a project's purpose is defined too narrowly and, therefore, is invalid. Such a general rule is consistent with the directives encouraged by both prior caselaw and CEQ regulations. ${ }^{109}$ Courts have required agencies to consider taking no action as an alternative, ${ }^{110}$ and have additionally endorsed consideration of lesser action ${ }^{111}$ or delay. ${ }^{112} \mathrm{CEQ}$ regulations also provide that mitigated action is a permissible alternative under NEPA. ${ }^{113}$ Such a general rule would ensure that agencies examine reasonable alternatives in every EIS, as required by NEPA's broad language ${ }^{114}$ and by the courts.

\section{Part two: The objective inquiry.}

If EIS alternatives are presented, the court should then objectively examine the project's purpose. To do this, courts must obviously reject the D.C. Circuit's narrow formulation. ${ }^{116}$ However, the general goal formulation as stated by the Seventh Circuit, ${ }^{17}$ while consistent with NEPA's purposes, makes no definitive attempt to address what it is that the general goal formulation seeks to achieve, or provide tools to evaluate a project's purpose. To conduct its hard look review of the agency's position, therefore, courts must develop objective criteria with which to evaluate the EIS.

109 See notes $84-85,90$ and accompanying text. See also 40 CFR $\S \S 1502.14(d)$, 1508.25(b)(1).

110 See, for example, Seattle Audubon Saciety v Moseley, 80 F3d 1401, 1404 (9th Cir 1996) (per curiam) (rejecting argument that failure to consider "no action" alternative was unreasonable in the context of assessing alternatives for old growth owl habitat).

111 See Simmons, 120 F3d at 669 (suggesting that the EIS should consider the construction of a shorter pipeline as "at least one concrete alternative that seems reasonable").

112 See, for example, Alaska $v$ Andrus, 580 F2d 465, 474 (DC Cir 1978) (finding that the Secretary of the Interior was required to consider the alternative of delaying government action until the completion of several potentially useful environmental studies).

113 See 40 CFR $\S 1502.14$ (f) (directing agencies to include "appropriate mitigation measures" in EISs); 40 CFR $\S 1508.25$ (b)(3) (requiring agencies to consider "mitigation measures [ ] not in the proposed action").

114 See 42 USC $\$ \$ 4331-32$.

115 See, for example, DuBois v United States Department of Agriculture, 102 F3d 1273, 1288 (1st Cir 1996) (holding the Forest Service EIS inadequate for failure to consider alternative sources of water, such as artificial water storage, for snowmaking in ski resort development); California v Block, 690 F2d 753, 766-67 (9th Cir 1982) (holding that EIS did not include an adequate range of alternatives to the proposed action of allocating roadless national forestland among three management categories); Environmental Defense Fund v Froehlke, 473 F2d 346, 348 (8th Cir 1972) (holding the Army Corps of Engineers' EIS was "too vague, too general, and too conclusionary" because it failed to consider alternatives to a proposed river channelization project in sufficient detail); Morton, 458 F2d at 834-37 (requiring agencies to consider alternatives that cannot be accomplished by the agency alone, including legislative action).

116 See Part III.A.

117 See Part II.A.1. 
In practice, the objective inquiry is an impartial assessment of the stated purpose to determine whether the purpose needs to be more broadly defined. To make this assessment, a number of factors can be considered, including but not limited to: (1) a limitation on geographical area or location, (2) a limitation in means or tools of production, (3) a specific method of implementation, (4) the existence of a totally inflexible timeframe, or (5) a favored form of technology. Reviewing the stated project purpose in light of such factors will then allow for the proper consideration of reasonable alternatives (in other words, adequately addressing the inquiry of what are the reasonable alternatives to the project as required by Morton).

For example, in Citizens, the project's stated propose was limited to one airport location. ${ }^{118}$ Thus, the purpose may require a broader definition because the purpose was limited to one geographical location. In addition, other means of production may be available, and a stated purpose which contains only one tool of production is insufficient. For example, in Van Abbema, the court needed to broaden the project's purpose as it mandated a specific means for delivering coal, in that case by building a transloading facility. ${ }^{119}$ And in Simmons, the stated project purpose was to build a single reservoir to increase the water supply. ${ }^{120}$ Applying the objective test in these two cases would have quickly led the court to the conclusion that the stated purpose was too narrow, instead of subjectively announcing the underlying goal absent any stated criteria.

Similarly, in Kettle Range, ${ }^{121}$ the method of timber harvesting was explicitly stated in the purpose, while in Muckleshoot Indian Tribe $v$ United States Forest Service, ${ }^{122}$ a specific land swap was stated in the purpose as the method to consolidate land ownership. In Friends of Southeast's Future $v$ Morrison, ${ }^{123}$ the purpose stated a specific amount of timber that should be sent into the market. In these three cases, the text of the project's purpose mandates a specific method for which to achieve a more general goal, and thus suggests that the purpose needs to be more broadly defined.

118 See note 7.

119 See text accompanying notes 49-51.

120 See text accompanying notes 54-59.

121148 F Supp 2d at 1117 ("The purpose of this project is to respond to the Douglas-fir beetle outbreak by restoring vegetation and aquatic ecosystems utilizing timber harvest.").

122177 F3d 800, 812-13 (9th Cir 1999) (approving an EIS whose stated purpose was to "enhance future resource conservation and management by exchanging parcels of National Forest System and Weyerhaeuser land").

123153 F3d 1059, 1066-67 (9th Cir 1998) (holding that the purpose of "providing 89 [million board feet] of timber to meet market demand" was not unreasonably narrow for an EIS, even if that statement of purpose eliminated the possibility of non-action). 
Favoring a particular timeframe or technology may also result in a project purpose being defined far too narrowly. For example, if the stated project purpose was "to build a research lab in one week," this may pre-ordain a specific site that can facilitate such quick construction. Courts should be wary of such inflexible timelines, and instead define the project purpose as "building a research lab." The court can then review the necessity of any such rapid timeframe when determining which alternatives are reasonable. Or for example, if the stated project is "to build an office building via technology X," the court should see the objective project purpose as "to build an office building" because "technology Y" may be a reasonable alternative.

\section{Solution advantages.}

Under NEPA, every agency is to some extent an environmental agency, as it is asked to consider environmental effects. Justice (thenJudge) Breyer's NEPA analysis in the First Circuit's decision in Sierra Club v Marsh ${ }^{124}$ has properly captured current law. NEPA's purpose is not to prevent environmental harm, but rather to avoid inadequate ex ante consideration. ${ }^{125}$ Permitting use of the narrow formulation can prevent consideration of alternatives, clearly circumventing NEPA's purpose.

Furthermore, the objective inquiry favors one of the very principles upon which NEPA was founded-public participation and involvement - by promoting the consideration and disclosure of a wider range of alternatives. By promoting this consideration and disclosure, an objective inquiry into a project's purpose will, in turn, increase opportunities for interested parties to shape the agency's EIS process and influence the quality of information that comes to the agency's attention, including a broader range of project alternatives. ${ }^{126}$ NEPA requires agencies to disclose alternatives that agencies would otherwise not consider when narrowly construing the project purpose, a goal that would be advanced by the objective inquiry's approach. ${ }^{127}$ Thus,

124872 F2d 497 (1st Cir 1989).

125 See id at 504 ("But the risk implied by a violation of NEPA is that real environmental harm will occur through inadequate foresight and deliberation.").

126 See Council on Environmental Quality, The National Environmental Policy Act: A Study of Its Effectiveness after Twenty-five Years 17 (1997), online at http://ceq.eh.doe.gov/nepa/ nepa25fn.pdf (visited Feb 22, 2003) (noting that "NEPA opened up for public scrutiny the planning and decision-making processes of federal agencies, in many cases providing the only opportunity for the public to affect these processes," and applauding NEPA for "opening the federal process to public input" since "this open process has improved project design and implementation").

127 See Taylor, Making Bureaucracies Think at 251 (cited in note 13) (concluding NEPA has caused agency insiders to "explore the possible environment-development trade-offs of a wide range of alternatives designs" resulting in "relatively inexpensive environmental mitigation"). 
increased judicial scrutiny of the project's purpose will increase the amount of quality information available and, ultimately, help agencies make better decisions.

\section{CONCLUSION}

Resolving the conflict of how to construe the stated project purpose under NEPA is imperative to promoting consideration of viable EIS alternatives. Despite its efficiency advantages, the narrow formulation should be rejected as inconsistent with NEPA's statutory language, legislative history, and purposes. Instead, courts should implement a two-part test for examining EISs. As a general rule courts should reject stated project purposes which result in the disclosure of no alternatives. In order to determine the project's true purpose, the courts should then adopt a broader, objective inquiry investigating the underlying need, effect, and aim of the action. Such an objective inquiry is consistent with NEPA's mission to increase public participation and improve agency consideration of environmental impacts.

128 See 40 CFR $\S 1500.1$ (c):

Ultimately, of course, it is not better documents but better decisions that count. NEPA's purpose is not to generate paperwork-even excellent paperwork-but to foster excellent action. The NEPA process is intended to help public officials make decisions that are based on understanding of environmental consequences, and take actions that protect, restore, and enhance the environment. 


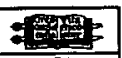

$$
\begin{aligned}
& 49
\end{aligned}
$$

